\title{
English Learning Mode and Strategy About Learning Curve
}

\author{
XU Li-mei, CHEN Qiang \\ Changchun University, Changchun, China
}

\begin{abstract}
How to realize the English learning effect optimization is an important problem that the current English education workers care about. Good English learning effect can reduce teachers' workload, and can also improve the students' English ability, thus provide more English talents for the development of economy. Based on the theory of critical period study hypothesis, this study describes the English learning curve of Chinese students and summarizes up the optimal model of learning English according to previous research, as well as the survey result of a part of Chinese students studying abroad, at last puts forward a variety of strategies, so as to provide theory reference for students’ English learning, and enhance the level of English teaching of China.
\end{abstract}

Keywords: English learning, learning curve, optimal model, learning strategies

\section{Introduction}

Since China's reform and opening up, the number of Chinese students to study abroad increased year by year with increasingly frequent communication between China and the world. The total number of all kinds of people study abroad in China is 2.6447 million by the end of 2012 from 1978. The annual growth rate of the number of Chinese people studying abroad is over 20\% from 2007 to 2012. Among them, the United States, Britain, Australia, Canada, and other English-speaking countries are the main purpose countries for Chinese students. It is important to note an obvious younger-age trend of studying abroad in recent years, namely more and more people go abroad to study for a bachelor. Behind this trend is the basic assumption that going abroad to study at a very young age would master a foreign language easily. However, is it right? Which age group of studying abroad has the best effect? How long it would spend to study abroad to master English fully and achieve the level of English countries of the same age? What strategies Chinese educators, parents, and students should take to achieve English education and the optimization of learning effect? This paper tries to summarize the optimal model of learning English, discuss the above questions and give answers (Anderson, Heinders, \& Jones-Parry, 2004, pp. 15-26).

\section{English Learning Curve}

This paper tries to describe the admission time and learning effect for Chinese students through the survey result of a part of Chinese students. The author conducted close observation and detailed interview with 16 mainland students aged five to 14 and would go to the US, Britain, and Canada. There are 12 students who will go

XU Li-mei, lecturer, master, Foreign Language College, Changchun University.

CHEN Qiang, associate professor, Ph.D. candidate, Public Foreign Languages Teaching and Research Department, Changchun University. 
to the US in the full sample, and four was born in the US. The author found that, generally speaking, it takes an average of two to three years to pass the ESL (English as a Second Language) test for the Chinese students who go to English-speaking countries from kindergarten to grade 6.

In addition, the author also investigated 12 Chinese exchange students and high school students at one's own expenses. The results of the survey show that their English language level failed to meet the level of mother tongue.

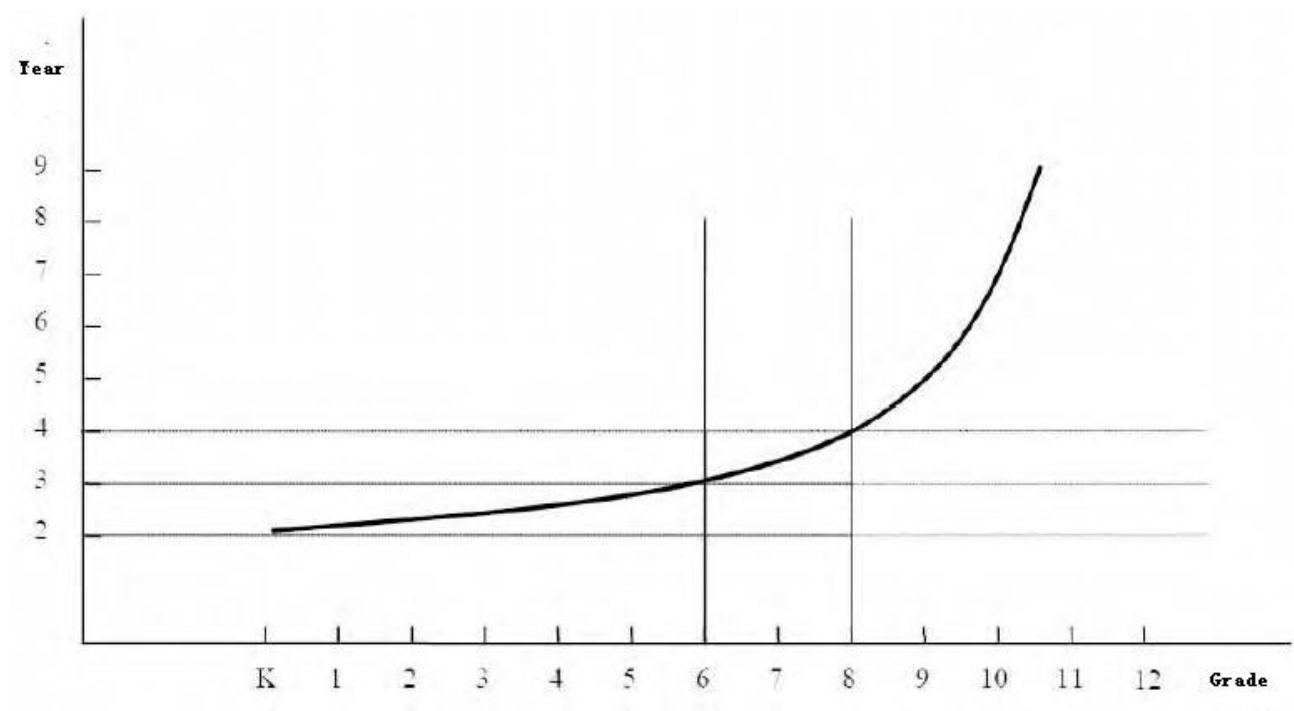

Figure 1. English learning curve of Chinese students.

On the basis of the survey, the author plotted a learning curve. Abscissa is the number of grade mainland students studying abroad, and coordinate is the time needed for the native language level. $\mathrm{K}$ to grade 6 is nearly two to three years, which needs less time, and the curve is flat; 7-8 grade is nearly three to four years, which need more time, and the curve starts to steep; when it is above grade 9, the time needed makes a sharp increase, and the curve is more steep. Thus, grades 1 to 8 is the critical period for learning English, grades 1 to 6 is the period whose efficiency is maximum, and 7 to 8 grades is the end stage of the critical period.

\section{Optimal Model of Study}

Chinese students studying abroad before going to college can be divided into the following several types: (1) short-term travel. Most short-term travel is in the summer vacation, there are a few in the winter vacation. The short-term travel takes less time, its systemic is not strong, and learning effect is not ideal (Aoki, 1999, pp. 142-154); (2) high school exchange or self-funded studying abroad. In high school, as general exchange students, they will study abroad for six months to two years, usually for one year. There are a few students going to high school abroad at their own expense, and mostly for two years. These students basically miss the end stage of critical period, and the time is too short, so they have a big difficulty in achieving the English level of native language; and (3) studying abroad for parents abroad. Most of the expats deadline is between one to three years, so the English learning effect of children has differences.

When putting forward the optimal model of learning English, people mainly consider four factors: The first is mastering Chinese, second is the English language level, third is students' learning characteristics and 
psychological endurance, and the fourth is operational. According to the different education system characteristics of the East and the West, this paper puts forward the following two learning modes on the basis of case study.

Pattern 1: Students study in English-speaking countries for two to three years during the primary school, then continue to study in China, and return to English to study in grade 10. Students will study six to seven years in China, and five to six years in English-speaking countries in this model. The advantage of this model is that the students can grasp well in both English and Chinese. But its disadvantage is that after backing to China, they may not keep up with the domestic courses in the near future. According to the English learning curve, studying abroad for two to three years in primary school can be up to the level of the mother tongue, so why going out even in grade 10 ? There are three reasons for this: (1) The level the students have reached is the level of elementary school at that time; (2) they just master listening and speaking at that time, vocabulary, reading, and writing also need to be improved; and (3) language skills they have mastered will be lost if there is no external environment or practice for a long time (Bandura, 1997).

Pattern 2: At the end of the crucial stage, send students to study abroad at the beginning of grade 7, so that they will study in foreign country for five to six years, which will make them have enough time to learn English well. The advantage of this model is easily to learn well, and the disadvantages are that Chinese vocabulary, reading, and writing is lacking.

In general, learning a second language well will spend at least five years, there should be two years or above in the key period of five. The five years of time can be divided into two segments, such as two years and three years. If it is two years and three years, two years should be in grade 1 to 6 , namely the first half of the critical period, and three years in high school; if three years and two years, it also can be done in the same way. The above is the model 1 and its variants. The authors roughly name the time in key period as the acquisition time, and the time outside of the critical period is learning time, so, Chinese students will need at least two years of acquisition time, plus three years of learning time. In addition, the five years above can be used as a whole, put it in any section in the 12 years, and ensure that there are two years in the key period at the same time. Considering the teaching tasks of primary schools and secondary schools in China are heavy, if the five years is put in primary school, the students' study in China will be very difficult, even cannot keep up with the same age students. Thus, people should put it in the last five years, which is the model 2 and its variants (Beetham \& Sharpe, 2007, pp. 1-10).

\section{Learning Strategies and Suggestions}

\section{Strategies and Suggestions in the Critical Period}

General strategy. Critical period is the golden age of English learning, so people should make full use of the learning time in critical period. In critical period, people can focus on listening and speaking. The best way to solve the problems of students' confusion in Chinese pinyin, English letters and International Phonetic Alphabet (IPA) more feasible is staggering the study time. For example, students begin to learn Chinese pinyin in grade 1, and English grade 3. In addition, people can also draw lessons from the practice of primary school, learning English from the beginning of the pronunciation, and then learning the IPA (Benson, 1994, pp. 3-12).

Study strategy. For the students hope to complete their studies and work abroad, they should take 
translation strategies in critical period, and also plan the time to go abroad to study reasonably. As mentioned earlier, to make China mainland students fully master English, they should study in English-speaking countries for at least two years in critical period. The specific practices of this strategy have two kinds: The one is studying English for two to three years during grade 1 to 6, then two to three years in high school; another kind is sending students to study abroad at the beginning of grade 7 until completing secondary school.

The authors have experimented with a reverse operation method, namely if students studied in English-speaking countries in a certain school year (Benson, 2005), then study Chinese in the summer vacation this year in China; if students study Chinese in a certain school year in China, then study abroad to the English-speaking countries in this year summer vacation. The students' level of the two languages will be quite balanced, and the effect is good.

\section{Strategies and Suggestions After Critical Period}

General strategy. For the students who missed the critical period, they should focus on reading and writing, and lower the standard of learning. Especially for non-English major undergraduate and graduate students, if they spend too much time and effort to learn English ignoring the professional study, it often does more harm than good. Therefore, the author suggests that ordinary standards of English curriculum standard should be reduced, and let students have more time to play their professional expertise.

It is necessary to point out that there are some Chinese students who learn English in primary and secondary schools, but choose small language at college; it seems that this is not wise, unless they have a special talent for language. For grade 7 to 9 is the end stage of the critical period for learning language, after that, the study cost will increase greatly, and it is difficult to achieve language level. Although there are less people choose small language, the employment opportunity is relatively more, but learn cost will increase, and the learning effect will be discounted.

The authors suggest that people should change the second language to the compulsory requirement, at the same time, encourage students to study mathematics, computer, economy, management, accounting, law, etc. (Benson, 2007, pp. 21-40), thus to broaden employment channels. At the same time, it is recommended that people should reduce the difficulty of all kinds of title English exam, and abolish some title English text which has nothing to do with English.

Study strategy. For the students who want to finish college abroad but realize employment development at home, they can finish primary and secondary school education in the domestic, and then go abroad to study. The authors note the following interesting phenomenon. It is assumed that there are two similar levels of Chinese students: The students of first group are in high school in China, and the students of second group study in the United States from grade 10. The students of first group often rank ahead of the second group admitted to the university in the United States, but the students in the second group are often easier than the first group to find a good job in the United States.

People have done in-depth research on the cause of the problem mentioned above. If the second group students finish high school in the United States, make them compete with American students, and they will be at a disadvantage when compete with American students. And the first group students are seen as international students, if they spend two years studying English and get a relatively high score, instead, they may be admitted 
by good universities. So even if students did not study abroad in primary and secondary school, they can also be admitted to the same or even better American university. However, in the university, the students of group 1 study better than group 2, but the students of group 2 are better than group 1 in the fusion of social culture. American employers hire employees according to their needs and abilities, so students of group 2 have an advantage than group 1 in terms of employment (Benson, 2008, pp. 15-32).

\section{Conclusion}

Learning curve has a very important significance for Chinese students’ English learning. People can arrange the time studying in domestic and abroad reasonably according to the learning curve, so that students will get a better education in China.

\section{References}

Anderson, H., Heinders, H., \& Jones-Parry, J. (2004). Self-access: Positioning, pedagogy and future directions. Prospect, (3), 15-26.

Aoki, N. (1999). Affect and the role of teacher in the development of learner autonomy. In J. Arnold (Ed.), Affect in language learning (pp. 142-154). Beijing: Foreign language Teaching and Research Press, the People’s Education Press \& Cambridge University Press.

Bandura, A. (1997). Self-efficacy: The exercise of control. New York: W. H. Freeman.

Beetham, H., \& Sharpe, R. (2007). An introduction to rethinking pedagogy for a digit age. In H. Beetham \& R. Sharpe (Eds.), Rethinking pedagogy for a digital age (pp. 1-10). New York: Routledge.

Benson, P. (1994). Self-access system as information systems: Questions of ideology and control. In D. Gardner \& L. Miller (Eds.), Directions in self-access language learning (pp. 3-12). Hong Kong: Hong Kong University Press.

Benson, P. (2005). Teaching and researching autonomy in language learning. Beijing: Foreign Language Teaching and Research Press.

Benson, P. (2007). Autonomy in language teaching and learning. State of the Art Article Language Teaching, (40), 21-40.

Benson, P. (2008). Teachers' and learners' perspectives on autonomy. In T. Lamb \& H. Reinders (Eds.), Learner and teacher autonomy: Concepts, realities, and responses (pp. 15-32). Amsterdam: John Benjamin. 